TOBY MILLER

EXPORTING TRUTH FROM ABORIGINAL AUSTRALLA 'POFIIINNS OF OUR PAST BECOME PRESENT AGANW, WHEAE ONLY THE MEEANCHOLY LGGHT OF OHGGN SHNES'

I don't think there can be any doubt that Aborigines have been the most important Australian exporters of social theory and cultural production to the northern hemisphere over the past century. How could one come to such a conclusion?

When Jock Given approached me to write this paper, he referred to a recent essay of mine. It began like this: 'When Australia became modem, it ceased to be interesting'. I ran the argument there that Aboriginal Australia had provided Europe with a 'phorographic negative' of itself. The essence of the north, secrered by the billowing engines and disputatious parliaments of the modern, could be secreted by examining 'the prediamante realities of the Antipodean primordial' (Miller T 1994, 206-7). Once Australia was a sovereign state, and able to deny Aboriginal people cirizenship, it was merely one more place filled with whitefellas. 'Australians' were transformed in northern hemisphere theory from dashing blacks living out of rime into dull Anglo-Celrs living our of place. Bur today, the country is recurned to the lists of international intellectual pleasure. Lawrence Grossberg announces it as the site for cultural scudies on the cover of Stephen Muecke's book about Aboriginality and culcural studies (1992) and elsewhere (Grossberg 1994, 17), and postmodern Aboriginal-style cover art provides a marketing ploy for Roucledge's greatest hits of Australian cultural and media theory (Turner G 1993).

So 1 arrived here with that provocation, derived from a previous publishing folly. My more general brief - to discuss the inrernarional circulation of Australian sociocultural ideas - is subsumed somewhat by this heritage; but not, I think, unnecessarily. Of course, we could look for the global trace of contemporary Australia by a form of desperate content analysis. Adding up references to it in the Manhatan ficrion of Jay McInerney, for example: eight in Brtgbt Lights, Big Ctry (1986) if you count the 1984 New York Post, none if you don't; four in Ransom (1987); ten in Story of My Life (1989) if you count each mention of Nell's, three if you don't; and none in Brighiness Falls (1992). Or we could turn to the 1995 'Down Under' episode of The Simpsons, in which a State Department representative briefs the family on bilateral relarions: 'As I'm sure you remember, in the late 1980 s the US experienced a short-lived infaruation with Australian culture lthis is accompanied by a carroon-slide of Paul Hogan as 'Crocodile' Dundeel. For some bizarre reason, the Aussies thought this would be a permanent thing. Of course it wasn't the latter spoken before a slide of a boarded-up film theatre with 'Yahoo Serious Festival' on the decrepit buildingl.'

Alternatively, much could be said about the contributions made by the country's principal passport-holders in this field. My own quick list, compiled from popular repure and academic citarional texts follows, in as idiosyncratic an order as possible; WK Hancock, Nick Cave, George Miller, Hedley Bull, Fred Emery, Coral Bell, RW Connell, Felix the Car, Elizaberh Grosz/Gross, Martin Indyk, Meaghan Morris, Joan Surherland. Dennis Altman, Parrick Whire, VG Childe, Tony Bennerr, Mudrooroo Nyoongah/ Mudrooroo/Mudrooroo Narrogin/Colin Johnson, Jill Ker Conway, Errol Flynn, INXS, Colin Clark, Rolf Harris, Gillian Armstrong, B Wongar, Robert Hughes, Clive James, Yothu Yindi, Rupert Murdoch, Michael Taussig, Alan Donagan, Bob/Robert/RIV Hodge, 
Peter Weir, Gunther Kress, Air Supply, Elton Mayo, Kylie Minogue, Malcolm Williamson, AL Burns, Fred Schepisi, Julius Stone, Boris Frankel, Sidney Nolan, Rick Springfield, Graeme Turner, Tracey Moffatr, Paul Hogan, MAK Halliday, Jane Campion, Judy Wajcman, Wilfrid Thomas, John Passmore, and Jack Davis. I do not seek to minimise the significance of their achievements or of ochers who might be added (briefer residents such as Enoch Powell, John Fiske, or the Bee Gees). I want 10 argue, however, thar no ser of nominared individuals exercises the significance outside Australia that Aborigines have done, and continue to do, as a collectivity, via their uptake by forms of social and cultural theorisation dedicared to understanding modernity and its post.

I wish to emphasise the following limitation to the paper at this point. It is negative critique. I am concemed here with the use of Aboriginality as a theoretical trope by whire people, not with the actual details of what could or could not be regrouped retrospectively under that sign. I am wriring. therefore, as an historian of white intellectual discourse outside Australia, not of black thought itself.

If you turn to the principal European and American sociocultural writers from the 1820 s to the 1960s - Georg Hegel, Karl Marx, Sigmund Freud, Érnile Durkheim, Marcel Mauss, Frederick Engels, Gaetano Mosca, AR Radcliffe-Brown, Ruth Benedict, Talcott Parsons, Claude Lévi-Strauss and Clifford Geertz are my arbitrarily selected sample here - you find Aboriginal Australians' notions of human classification, duty and social organisation taken as critical keys to understanding lost truchs of humanness (something I first noted following a conversational aside from John Hartley). These truths are held to have been submerged in European and American moderniry through the sweeping changes of industrialisation, urbanism, representative democracy and production-line culcure. Not many of these theorists had much to do with Australians face-to-face (Mauss, for example, acted as a translator between French and Australian troops during the Great $W a r$ and called himself a museum ethnographer [Foumier 1993, 332; Mauss 1993. 71); but nor did they need to for the purposes of their work. So what did they make of this distant world? Durkheim provides half of the faux quotation that gives this essay a title. He saw the study of Aboriginal people as a way to make 'portions of our past become present again' (1961, 22). Europe's modernity had weakened its version of the affective bonds that provided the grout holding societies rogether, in favour of an intense process of individuation. Nevertheless, 'the ensemble of mental habits' clearly on view in black Australia was still at work in Europe; submerged perhaps, but operant as classificatory mechanisms for coordination and hierarchisation (Durkheim \& Mauss 1970, 88). Only the primitive, particularly its Australian variery, could provide Benedict with her desired "laboratory within which we may study the diversiry of human instirutions' (1959, 17, 26, 33). And for Freud, the 'savage and semi-savage races' are of 'peculiar interest for us, for we can recognise in their psychic life a wellpreserved, early stage of our own development'. His Totem and Taboo places particular faith in combining knowledge of First Peoples from 'folklore' with 'the psychology of the neurotic', from analysis. He goes off in search of correspondences between the two, and the youngest continent, namely Australia' offers a perfect instance via Aboriginal insticutions and beliefs $(1946,3-5,40)$.

\section{SEARCHING FOR THE MODERN}

John Harcley argues that the exterminarion of the Aboriginal people proposed by the likes of the Sydney Morning Herald in 1844, and taken up by populist activity in New South Wales and Van Diemen's Land, was actually more than a racism that marked out differences between white and black in a gruesome way. It was also a means of differentiating the colonists from Britain, an expression of singularity that helped to bring a national identiry into discourse. This was part of the long haul to shift the signifier of 'Australians' to indicare 'white inhabitants' rather than 'Aborigines', who instead come to be known as 'our Aborigines' or 'Aboriginal Australians'. They lost the master signifier along the way. By 1951, the Herald and Weekly 'Times' Great Jubilee Book, issued to commemorate the first half-century of Federation, could respond to its question 'Who are the Australians?' with a British/ 
European answer. The volume's only reference to Aborigines came 'for the record', listed alongside Chinese, Afghans and Indians as the country's 'full-blooded non-Europeans'. Conversely, generations of young Britons had their version of the mission civilisalrice enunciared in textbooks that utilised the Empire's positive treatment of Aboriginal people as an index of its moral superiority (Hartley 1992, 201.4; Stratton 1989, 133-4). Clearly, Aborigines were testing grounds for Britain: to be cleared from their territories by colonial subjects bent on a project of nation-building via the economical use of space and time, but/and to be protected in those territories by distant governors dedicated to a project of empirebuilding via the moral management of those same coordinates. 'At home' (in Australia), dealing brutally with the problem of the indigenous people became a meter of progress, of fitness for independence. 'Back home' (in Britain), showing clemency to Aboriginal people was a measure of maturity, of fitness for world leadership.

Outside this specific imperial technology, a complex dialectical play between economics and government, Aboriginality avanl la lettre was critical for an understanding of the project of modernity. Hegel regarded (black) Austratians as 'culturally inferior' and 'immature' even in the form of their geography $(1988,163,162)$, Durkheim's sociological classic The Elementary Forms of the Religlous Life, first published in 1912, was based on Aboriginal material, specifically the Arunta people. This is somewhat hidden in many English translations, which leave out the subtitle, La Système Tolémique en Australie (The Australian System of Totems) or render it as A Siudy in Religious Soctety. Durkheim's armchair account of totemism and the basis of religious forms of life remained the standard account of the phenomenon for years. His explanation of how the social world of ritual imposes obligations on its members towards venerated objects was fundamental to theorising the strange relationship enacted berween Christians and the first day of the week, and then on to understanding intersubjectivity in general rerms (Radcliffe-Brown 1976, 123, 130). Durkheim's earlier work with Mauss (1970), also based on 'the Australians', established agendas for theorisation and fieldwork in the developing area of social anthropology in Britain, France and the Nerherlands. Symbolic classifactions were investigated from China to Greece, in accordance with Aboriginal standards (Needham 1970, xxoxiii).

Elementary Forms examines the most primitive and simple religion which is actually known'; simple in terms of straightforward social organisation, and simple because it is sealed off from ather forms of sacred life, unlike the leaky ecumenicism/ conflict of European faiths. Durkheim defines his work as an atrempt to explain an 'actual reality which is near ro us, and which consequently is capable of affecting our ideas and our acts'. This 'reality is man, and more precisely the man of roday'. Aboriginal ways of life are deemed 'better adapted than any other to lead to an understanding of the religious nature of man'. His choice is determined by the promise that the premodern will enable him to find the common foundation of the religious life underneath the luxuriant vegetation' that overlays it in industrial society's heterogeneity and bizarre propensity for individuation. Although 'the lower religions' are 'rudimentary and gross', thar very fact 'makes them instructive, for they thus become convenient for experiments' (1961, $13,17-8,21)$. Across the political divide, Engels' theorisation of the origins of capitalist society draws heavily on comparative material that includes Aboriginal tribes, whose legal system he much admires (1978, 15-6, 46-51).

This unspoilt terrain also provides material for the fin de siècle Iralian Machiavellians, or elite theorists, such as Mosca. His thesis of the inevitability of oligarchy draws on anthropological reports of Aboriginal life to stress not so much evolutionary superiority as the power of imported knowledges, technologies, diseases and warfare to displace prior modes of production. This is the liberal side to Mosca that seeks to counter notions of innate white rule by reference to the historical specifics of white domination (1939, 21-3). For Parsons, on the orher hand, there is a clear heuristic pleasure in equating Aboriginal Australia with primitive forms of social organisation, because of its economic simplicity and kinship affinities. These qualities make 'Australian sociery' 
undifferentiated, a sin for high-priests of the modern but also a useful measure of their own evolutionary narcissism (1966, 35-6, 41).

And for linguists and anthropologists across the world, 'Australians' has concinued to signify black, not white, life (Dixon 1980). So when Radcliffe-Brown delivers the Henry Myers lecture to the Royal Anthropological Institute in 1945 on 'Religion and Society', his discussion of ribal kinship is glossed as an account of 'Australian society'. There is a dual significance in this seemingly unorthodox alignment of signifier and signified. Firstly, Radcliffe-Brown is drawing conclusions about the sinctural homology and aetiological intersection of the two concepts in his title. They are thought to offer models for seeing 'religions in action' elsewhere $(1976,169)$. In the process, differences between Aboriginal groups are erased (Stratton 1989, 134-35). Secondly, and this is an implicit point, 'Australia' is of interest insofar as it signifies 'Aboriginal'. The country's status as a white setcler colony promises little if anything for the domain of social theory. Once 'Australians' are white, they are cruly uninteresting.

The disarticulation of the sign from its referent undergoes a fascinating rearticulation in Australian sociology. Introductory texts for undergraduates often comprise valuable discussions of Aboriginal social conditions. But their theory sections continue to be exegeses and distillations of European social thought, minus the originary context. In short, theorists of modernity who relied on exported accounts of Aboriginal life co undergird their work are imported to Australia sans their anchor. So it becomes possible for Donald Edgar in Introduction to Australian Society to reference Durkheirn's Elementary Forms as a means of knowing 'the emotional bonds to which we attach moral ideals'. There is no indication that this book was grounded in Aboriginal society. In fact, Edgar's exemplar of how contemporary Australian readers might test Durkheim's seemingly transcendental finding is seeing what happens if these protosociologists 'refuse to stand up for God Save the Queen' $(1980,94-5)$.

\section{SEARCHNIG FOR THE POSTMODERN}

Worrying away at this question of origins and authenticity inevitably propels us past modernity 10 its unsteady successor. Consider these four sites:

- Philip Kaufman's The Right Stuff (1983) includes two spectacular encounters between NASA astronauts and tribal Australians. The first is a complex discussion over the relative merits of Aboriginal and North American guidance systems; the second, a mystic moment of salvation for Ed Harris's troubled capsule courtesy of the smoke from an Aboriginal ceremony.

- Tracey Moffatt's films draw applause from feminist theorists E Ann Kaplan (1989) and Patricia Mellencamp, notably in the latter's brilliant, redemptive reclamation of the avant-garde and history for women directors of colour (1993-94).

- Wim Wender's Until the End of the World (1992) returns us to the pre-Psycbo days of Hollywood horror via a mad scienrist who is assisted by Aboriginal technicians in his efforts to visualise dreams (ie black Auscralian cosmology made palatable for media mavens).

at New York's Asia Sociery in 1988, Billy Stockman and Michael Nelson of the Papunya Tula Arts cooperative construct a 'sandpainting'. The Asia Society ships in three tons of sand from Long Island to assist in the production of Central Desert mimesis. But Stockman and Nelson prefer to paint on the masonite floor (which is nice and red) because the watered sand does not develop the surface they are accustomed to working with. Nevertheless, the men consent to use the introduced materials when admonished by Asia Society officials that 'we advertised sandpainting' (Myers 1994, 679-80, 690).

And black Australians signify something important in recent self-help technologies as well. Consider the work of Marlo Morgan. She went to Australia because the US health system was not supporting her work for 'wellness'. The immensely successful book detailing her experiences there with Aboriginal people (23 weeks on the New York Times Book Review best sellers' list in 1994-95) and its accompanying videotape Mutant Message Downunder (1993) are very enlightening; and I choose that word with careful abandon. For Morgan is a muly redemptive, American soul. She reaches deep into the rich lode of Protestant desire 
and denial to mock her own secularity and pomp, leavening it with a primitivist spiritualism that can then be peddled on retreats for the terminally anxious (who are also terminally affluent) at the 'Survival Centre', where her reminiscences and prescriptions from Australia were recorded on tape. The video slick logos promoring her company have outline maps of Australia and the US superimposed on one another and a black kangaroo nestled against (one out of) cross-sections of teeth, burtes from John Ford's Stagecoach (1939) drive through Monument Valley, or perhaps the upper reaches of a cactus. The slick also indicares that although Morgan's 'education spans four continents and includes multiple degrees' she encountered 'her most valuable teachers nor at the universities and clinics but instead the primitive, illiterate Australian Aborigine bush people of the wild outback desert'. She is recorded in a single-camera set-up in a medium shor that somerimes zooms uncertainly in to medium close-up: redolent of stand-up comedy or, perhaps. given the narrative that unfolds, IMarried a Monsier from Outer Space (Gene Fowler Jr, 1958).

Morgan removes her watch at the commencement of the video-lecture in order to mimic Aboriginal time, undertakes to dig a hole in the stage to create a 'potry', and then offers the following about going to Ausrralia: 'I gave away everyhing I had and left Kansas'. It was her first time as an adult that she had nor possessed the key to a door. After initial inner-city encounters she caregorises urban Aborigines as alcoholics. White Australians respond to her critiques of their neglect by saying 'Abos' do nor have a European sense of time, will nor leam to read and write, and go 'walkabour', making them unemployable. Marlo mocks her own condescension as a person claiming to understand life, money, and the self. Such notions are 'pretry asinine'. But the company succeeds and she feels very proud.

When she meets tribal Aborigines, Morgan is required to undergo a huge transformation. They offer her 'a big rag ... and it was well-used' in order that she can be 'cleansed' by wearing no underclothing. As part of her initiation into Aboriginal ways, she is made 'filthy'. She is undergoing 'resting' to go beyond behaviour and looks, to question 'in the very moral of my bones in my guts ... who was I really? Such selfexamination is essential because of the Aborigines' experience with meddling ministrations from Christians. Then she is invited on a 'walkabout ... across Australia" (this is illustrated on the video by a sign reading 'WARNING NOTHING AVAILABLE NEXT 1000 KILOMETRES'). Morgan explains that she cannot go because of bills and governments and foreignness. But she is then told she has been chosen: she needs this experience if she is to develop as a person. On the walk, her feet are grievously injured. But she puts up with bleeding, blisters, and intense heat. Now in the middle of a grand process of renewal, Morgan transcends pain, 'walking around on these stubs you're borrowing. They aren't really yours'. Fourteen hundred miles are covered in four months: 'They unwound everything I stood for ... There isn't anything in me thar is the same as it was then ... I don't eat the same, I don't look the same'. Each morning in the deser 'I would look our. And there's nothing out there. Really nothing'. But blacks are excited about each day and what to do. For them, 'every day is a wonderful day'. As they get up each morning, Aboriginal people in the desert stand like a satellite dish' and speak 'to the world': persona nullius at work in serra nullius.

She learns that 'You are not your body', an insight that leads to loud applause from the Cartesians in her 'Survival Centre' audience. 'You only have a body.... Let your self get out of the way'. Ego disappears. In the process, Morgan learns from her companions that all people have all talents and that it is 'very important to live in harmony with the universe'. No pollurion has ever been caused by Aborigines, nor any environmental hazards. All materials that they use 'can go back to the earth'. For these are non-judgmental, non-hierarchical people. Dispures are resolved by putting a person physically in the place of her adversary (a nice tribal instance of Gestalt psychology and ideal communicative rationaliry). Aborigines are 'like wonderful, wonderful children', but 'wise' as well. This wisdom is contrasted with her own folly. She is a 'mutant' (their term for white people who do not eat naturally occurring food, have allergies to nature, and suffer mental illness). Unlike the murants, tribal people routinely live ro 110 . These remarkable 
actuarial findings arise because Aborigines 'have avoided the Australian government totally'. At this point, the tape cuts to a graphic of black birds in flight, then back to Morgan: 'I now see ... like an Aborigine'. And whereas 'ihe mutant response' to, for example, a child's nightmares may be denial of the dream's reality, the Aboriginal (and post-mutant) reaction is to ger metaphysical about it.

Prayer is said for her 'on the day thar I was released to go back ro my sociery'. Bur she is now thoroughly primordialised and has even 'developed a hoof' on the bottom of her foot. Morgan 'felt beautiful' until she saw herself in the window of a store, 'at the level of a beggar'. Previously critical of street people begging, she now understands. The prayer of departure had talked about changing the mutants: 'they seem to understand truch, but it's buried'. The chief criticism of such figures is their ephemeraliry. The Aborigines said of her, 'We have selected this mutant as our messenger', a bird 'to tell the world that the real people are leaving'. Her arms are upraised at this point, perhaps in praise to her publishing house.

\section{What is going on here?}

A projection back to Eden was integral to the longing of the modem to know itself through a differentiation from the 'primitive'. Put another way, the use of Aboriginal life to illustrate the teleological motion endorsing advanced industrial societies also contained its share of melancholic nostalgia for simplicity. With the shift to the postmodern, this idealisation reestablishes the citability of 'Australia', as we can see in the work of LeviStrauss. He regards 'the Australians' as 'backward on the economic level', bur 'so far ahead of the rest of humanity' in terms of harmonious social relationships that the complexity of their organisation can only be comprehended via 'modern mathematics'. The ties of marriage bonds and their associated theorisation as law embody successful life management and represent the first speculations over what this entails (Levi-Strauss 1983, 343).

Similarly, Warlpiri art becomes a central strut in Daniel Miller's reclamation of marerial culture as an inevitable form of objecrification, rather than somerhing that is part of an alienating decline into industrial and postindustrial society as per the romanticism of Hegel and Marx (Miller D 1987). Looking back on the difficulties of universalising about 'man' from a base in ethnographic reportage, Geertz wonders whether we can 'grasp him' via 'those fantastic Australian marriage rituals'. (I presume he is nor referring to the late Senator Murphy's legacy of the Family Law Acc.) In sync with the new particularism of the postmodern, but still in the thrall of the generality of classical theory, Geertz suggests that 'the cultural particularities of people - in their oddities' may reveal the best possible trace 'of what it is to be generically human'. In a notorious phrase, he avows: 'Every man has a right to create his own savage for his own purposes' (1973. 43, 347). And the new uptake of Mauss as a scion of anti-depth performativity in his account of infinitely disposable masks of/as the self shows little direct engagement with the Aboriginal ideas on personhood that are critical to his position (Mauss 1993, 12; for recent rediscovery, see Carrithers et al 1993).

This rendency for oursiders to find the modern and the postmodern in black Australia, with white Australians proceeding to follow their theoretical lead minus its empirical underpinning, reaches its apogee in the second half of my titular faux quotation, with Jean Baudrillard's identification of 'the southern lands, where only the melancholy light of origin shines'. He nominates 'Australia' as 'a kind of spaceship' on an other-worldly orbit. Like a true Hollywood NASA-man or 'Survival Centre' graduare, Baudrillard manages to connect the teleparhic ecosystem of the Aborigines' with our 'hypermodern, hyperreal future' $(1990,161,164)$.

For its part, cultural studies' relentless quest for new fields ro conquer helps in this colonisation of Aboriginal life; with a different intellectual agenda from modern social theory and psy-discourse, but using remarkably similar methods. The mammorh (600-page) new book Cultural Politics represents a major play by Basil Blackwell to produce an undergraduate-style text that uses cultural sludies to explore non-media arts. Significantly for my purposes here, authors Glenn Jordan and Chris Weedon go looking for their subritle - Class, Gender, Race and the Postmodern World - from a base in Wales that allows them to write 
about the rest of us. Specifically, their demonisation of the white middle class ethnographer' (never named or engaged with) and their appropriation of Aboriginal literature (never considered in terms of its theoretical/critical apparatus, just read from Glamorgan) underwrites attemprs to find our about the overall nature of 'CULTURE, POWER and SUBJECTIVITY' (1995, 490, 498).

And they are not alone. Consider the Modern Language Associalion, a US-based organisation of 32,000 litterateurs - what a thought that is. Its flagship journal, $P M L A$, recently published a theme issue on 'Colonialism and the Postcolonial Condition' dedicated to foregrounding the relationship of criticism to the self and its other. The introductory essay is illustrated with the British theorist and phorographer Victor Burgin's 'double image of Australia's history' from the invasion bicentenary. His Unlitled is comprised of two adjacent squares. One has a white backdrop with a map of Australia, coloured black, and ' 1788 ' in black type. The other is a reverse print, with ' 1988 ' in white type (Hutcheon 1995, 8). Here, the postcolonial is sharpening the politicised project of contemporary cultural critics, simultaneously decentring imperialism in favour of peripheral sites and focusing on how the Westem core has defined itself logocentrically via the otherness of colour.

This tendency extends into a love of the counter-indicative, evidenced by seemingly endless secondary references to the nonvictim status of Aboriginal viewers of television, such as the beliefs of young audience members that African-American situation comedy acrors are Aboriginal, or the fact that tribal communities interpret Hollywood films on video against the grain (originally repored in Hodge \& Tripp 1986, 138-42, and Michaels 1994, 81-95; cited in Fiske 1988, 316, 320; Fiske 1989, 57, 137, 166; Fiske 1993, 128; Hay 1992, 361). Similarly, Sean Cubitt's readership in Liverpool enables him to herald 'Warlpiri experiments with television in Western Australia' as 'Third Video', dedicated to resistive communication via an incense localism that demonstrates the anomic, falsely individual address of 'Western TV' $(1993,173)$.

Another sign of the postmodern: it's hard now to produce the old form of classic ethnography, one that essays a comprehensive engagement with an overall way of life. Anthropology is fallen under the metacritical spell cast by textual analysis, and the area's distributional lodestone - US publishing - increasingly seeks crossdisciplinary sales fields combined with American subject matter. We can see the intersection of these tendencies in the form of two recent books by major North American scholars: Fred Myers' Pintupi Country. Pintupl Self (1991) and Eric Michaels' Bad Aboriginal Art (1994). The contrasts and connections between these two books serve to summarise and exemplify what I have been trying to say throughout this article.

Pintupi Country may well be one of the last grand-scale ethnographic accounts of tribal Australia. Much has already been documented, and few groups continue hunting and gathering as a form of life. As I indicared above, intellectual fashion decrees the need for self-reflexivity, autocritique, and a new kind of fieldwork (time spent over the word-processor and the mirror). This is not to say that Myers' work is out of time (consider the feminist uptake by Weiner 1992, 98-130). It is very careful to theorise the self, both the one who writes and those who are written about. As well as this, Myers overtly imports and refines social theory in the context of what he encounters, acknowledging the uniqueness and the ordinariness of life in the desert. He refers to 'Pintupi political theory', a memorable phrase indeed. (If you look at white Australian works of 'political theory', Aboriginal materials are sparse indeed, even when 'the primitive' is troped ICondren 1985; Miller JDB 1967, 1981; for primitivism, see Bull 1977, 59-60).) Myers talks very pointedly abour how Pintupi theory excludes communicative ethics: political culture takes a neo-Wittgensteinian form that projects each experience into a forthcoming possibility, where precedent is all, but is itself known through an intersection with the moment at hand (1991, 284-5).

Despite this careful work, his efforts drew intense obloquy from Michaels (1987a, $1987 \mathrm{~b}$ ) in a multiply published review arricle. This led to a point-by-point refutation (Myers 1987). That intellecrual history is lefe untraced, however, wirh the 
latest reprint of 'If 'All Anthropologists Are Liars...; in Bad Aboriginal Ant. The essay provides Dick Hebdige, of Valencia, Califomia, by way of Birmingham and orher British centres, with a take-off point for distinguishing Michaels' work from conventional social and culrural theory, with Myers as his bad object. Hebdige finds 'a comprehensive critical agenda for crosscultural communications research in the $1990 s^{\prime}$ in the Michaels book (Hebdige 1994, $x)$. This is not surprising; it is one more stage in a lengthy history of First World people writing about tribal Aboriginal forms of life and then exporting this back home, with a subsequent elevation of status for themselves and a renewal of critique for academic theorisarion. What surprises, given his own activities in this domain, is Hebdige's amnesia about systems of thought and forms of academic iranslation. Commitred to repear a well-established past, he welcomes the fact that Michaels' Warlpiri fieldwork surpasses 'the stans of a case study', which would amount to 'a diminution'. Instead of some 'poignant foomore in the triumphalist history of capitalist development and/or cultural imperialism', Bad Aboriginal Art demonstrates the general pertinence of Aboriginal appropriation and adaptation strategies for anyone interested in developing alternative models of TV producrion, distribution, and reception'. Not surprisingly, this heroisation tropes the postmodern in its endorsement of selfreflexivity; specifically, 'the final coup de grace' that Hebdige claims is delivered to Myers' work for failing to meet this test of cultural studies narcissism (Hebdige 1994, xiii-xiv, xviii, xxiii-xxiv). This is, again, an astonishing claim, given the pains that Myers goes to in Pintupi Country to theorise his own position. But it is the same kind of error that armchair citational practices routinely produce, and it matches the slide of the signifier that erased Aboriginaliry from the sources of modern social theory, precisely by negating the specificity of 'case studies'. Postmodern cultural theory brings itself into being via the very strategies that it claims to deplore.

Mention of Michaels inevitably leads us to his much-vaunted production work with the Warlpiri people, and Francis Jupurrurla in particular, on indigenous media. What better instance of First World adventurism played out on Aboriginal theory can there be than an American anthropologist decreeing 'The Aboriginal Invention of Television'? The latest (fifth) edition of Horace Newcomb's now-standard US textbook of readings on television is in some sense bound together by Michaels' account of Central Australia, even though the volume is remorselessly focused on the United States through exciting analyses of Rosanne, Nortbem Exposure, Married with Cbildren, and so on. Newcomb's introduction claims that the Yuendumu community's encounter with relevision 'encompasses and capsulises la splendid Americanisml every issue touched on in this collection'. Now Newcomb's project is essentially a North American brand of left Leavisism, dedicated to 'the making of critics'. Michaels' essay is suited to this project because it models the intrication of 'the aesthetic and ideological, the cultural and social, the context of home and the context of nation, the application of practical politics' (Newcomb 1994, 12-3). In shorr, Michaels is replaying Durkheim's findings on the essence of religion and socia! life, this time transcending spiralling smokestacks and anomic loss of community to reveal the nature of television (not society) to those living in the First World. And more than that, Michaels' deeply moralistic stances model perfectly Newcomb's claim that it is the responsibiliry of critics to perform ethical exercises as part of their vocation to aestheticise from selfdecreed vantage points on the cusp between the modern and its post (1994, 502).

Bur, of course, Michaels represents a small part of the very rich terrain of production work in the area, panicularly by comparison with Neil Tumer, Anmanari Nyaningu, and Pitjantjatjara EVTV at Ernabella, or the achievements in the first days of CAAMA (Turner N 1990; Batty 1993a, 1993b; O'Regan 1993). Perhaps the most important academic contribution to the export of these ideas and practices comes from Faye Ginsburg's synthesis of Australian Aboriginal media experiences and theories with those of other First Peoples (1989, 1991. 1993a, 1993b, 1994a, 1994b). As she says, 'Aboriginal media has triggered interest worldwide for indigenous groups that have formed alliances around the production of their own media'. At the same time, 
Westerners are 'fascinated by the seeming disjunction of Aboriginal people stereotypically identified by their relatively simple material culrure and distincrly nonWestern cosmology - working comfortably with the latest in sarellite and video technologies' (1993b, 92). Her work has helped to bring 10 intemational prominence the ABC's Aboriginal Programs Unit. But beyond that, it is significant that Philip Batry and Freda Glynn were joint recipients in 1993 of Canada's presrigious McLuhan medal and $C \$ 50,000$ prize for contributions to international media, in recognition of their work with Imparja Television. This is far more than an academic phenomenon: Aboriginal TV has generated fearure articles in Rolling Stone and the former New Soctety (Ginsburg 1993a, 562).

At a theoretical level, Ginsburg's analysis has also helped to situate Aboriginal dilemmas over the media in a way that connecrs with other Fourth World issues and the very nature of the means and mode of communication in this fin de siecle moment. She suggests that indigenous media have been (mis)understood in two ways: as a compromise of tradirional custom in the face of electronic communication that pollutes former ways of life, and as the promise of transcendence/renewal through uropian contact over the ether with like-minded others (Ginsburg 1993a, 560-61). Something similar seems to be happening with the idealisation by world environment movements of Aboriginal life and its Arcadian harmonies (Turner B 1986, 90-91).

There is little room to develop these points further here. Clearly, a fine line has to be walked in engaging 'Australia' from elsewhere, between a sloppy appropriation that wilfully loosens the sign from its referent in the form of a continuing process of logocentric whire projection, and the desire to give some extraordinary political, theoretical, and aestheric developments in First People's media their due significance. In closing, we might exemplify this awkward oscillarion by turning to that strangely esteemed text, John Tomlinson's Cullural Imperialism (1991). Its frontispiece, an image of Aboriginal people sirring outside a house watching TV, provides the ur-moment for Tomlinson. The photograph 'immediately strikes an exotic nore', because 'It]hese people are obviously nor
Westerners'. He uses it as a conceit to pose the questions that inform the remainder of his book: the dangers of foreign television, the impossibility of knowing what audiences make of rexts, and the threats posed by culcural imports to indigenous culture; in short, dealing with the risks and promises of globalised modernity.

We are reminded here of the provocation that EE Evans-Pritchard made about sociologists who perused Australian erhnographies for an understanding of modern life's other: 'the theoretical capital on which anthropologists today live is mainly the writings of people whose research was almost entirely literary' (quoted in Needham 1970, xl). This is not the best way to be. Returning to Harley's argument about the destruction of Aboriginal people as a means of differentiating colonial 'Australians' from their British betters, we can now see a contrapuntal deployment of this croubled national sign. If the modern in Australia was announced by genocidal conducr - even as it was being defined elsewhere in relarion to the victims of that behaviour - then the postmodern finds a new national maturity declared by Paul Keating through a supposed reconciliation with First People (Tyler 1994, 5-0). Costs as well as boons will flow if we forget what this repetition involves.

\section{AEFERENCES}

Batty, Philip, 1993a, 'Singing the Electric: Aboriginal Television in Australia', in Cbannels of Resissance: Global Television and Local Empowerment, ed Tony Dowmunt, BFI, London.

1993b. Who Told You We Wanted to Make Our Own TV? The Broadcasring in Remore Aboriginal Communitics Scheme and the Failure of Policy', Arlink, 13, 1, 22. 24.

Baudrillard, Jean, 1990, Cool Memories, trans Chris Turner, Verso, London.

Benedict, Ruch, 1959, Palterns of Cullure. Houghton Miffin, Boston.

Bull, Hedley, 1977, The Anarchical Society: $A$ Sludy of Order in World Politics, Macmillan, London.

Carrithers, Michael, Collins, Steven \& Lukes, Steven. eds, 1993. The Calegory of the Person: Anlbropology, Philosophy, History, Cambridge UP, Cambridge. 
Condren. Conal, 1985. 'Political Theory', in Surveys of Australian Political Science, ed Don Aitkin, George Allen \& Unwin, Sydney.

Cubitt, Sean, 1993, Videograpby: Video Media as Art and Culture, St Martin's Press, New York.

Dixon, RMW, 1980, The Languages of Australia, Cambridge UP, Cambridge.

Durkheim, Emile, 1961, The Elementary Forms of Religious Life, crans Joseph Ward Swain, Collier, New York.

—, \& Mauss, Marcel, 1970, Primitive Classification, trans \& ed Rodney Needham, Cohen \& West, London.

Edgar, Donald, 1980, Introduction 10 Australian Society: A Sociological Perspective, Prentice Hall, Sydney.

Engels, Frederick, 1978. The Origin of the Family, Private Property and the State in Connection with the Researcbes of Lewis $H$ Morgan, Foreign languages Press, Peking.

Fiske, John, 1988, Television Culture, Routledge, London.

- 1989, Undersianding Popular Culture, Unwio Hyman, Boston.

_. 1993, Power Plays, Power Works, Verso, London.

Fournier, Marcel, 1993, 'Marcel Mauss ou le Don de Soi', Arcbives Européennes de Saciologie, 24, 2, 325-38.

Freud, Sigmund, 1946, Totem and Taboo: Resemblances Between the Psycbic Lives of Savages and Neurotics, trans AA Brill, Vintage Books, New York.

Geertz, Clifford, 1973. The Interpretalion of Cultures: Selected Essays, Basic Books, New York.

Ginsburg, Faye, 1989, 'In Whose Image? Indigenous Media from Aboriginal Central Australia:, Commission for Visual Antbropology Revtew, 16-20.

- 1991, 'Indigenous Media: Faustian Contract or Global Village?', Cultural Antbropology, 6, 1, 92-112.

- 1993a, 'Aboriginal Media and the Australian Imaginary', Public Culture, 5. 3, 557-78.

-1993b, 'Station Identification: The Aboriginal Programs Unir of the Australian Broadcasting Corporation', Visual Antbropology Review, 9, 2, 92-97.

-, 1994a, 'Culture/Media', Anibropology Today, 10, 2, 5-15.
—, 1994b, 'Embedded Aestherics: Creating a Discursive Space for Indigenous Media', Cultural Antbropology, 9, 3, 365-82.

Grossberg, Lawrence, 1994, 'Introduction: Bringin' It All Back Home - Pedagogy and Cultural Srudies', in Between Borders: Pedagogy and the Poltitics of Cultural Studies, eds Henry A Giroux \& Perer McLaren, Roulledge, New York.

Hartley, John, 1992, The Politics of Pictures: The Creation of the Public in tbe Age of Popular Media, Routledge, London.

Hay, James, 1992, 'Afterword', in Cbannels of Discourse, Reassembled: Television and Contemporary Criticism, ed Robert $C$ Allen, 2nd ed, University of North Carolina Press, Chapel Hill.

Hebdige, Dick, 1994, 'Foreword', in Bad Aboriginal An, Eric Michaels, University of Minnesota Press, Minneapolis.

Hegel, Georg Wilhelm Friedrich, 1988, Lectures on the Pbilosopby of World History: Intraduction. Reason in History, trans $\mathrm{HB}$ Nisbet, Cambridge UP, Cambridge.

Hodge, Bob, \& Tripp, David, 1986, Cbildren and Television, Polity Press, Cambridge.

Hulcheon, Linda, 1995, 'Introduction: Colonialism and the Postcolonial Condition: Complexities Abounding', PMLA, 110, 1, 716.

Jordan, Glenn \& Weedon, Chris, 1995, Cullural Politics: Class, Gender, Race and tbe Postmodem, Basil Blackwell, Oxford.

Kaplan, E Ann, 1989, 'Aborigines, Film and Moffatt's Night Cries - A Rural Tragedy: An Outsider's Perspective', Bulletin of tbe Olive Pink Society, 1, 2, 13-17.

Levi-Strauss, Claude, 1983, Stuctural Antbropology, Volume II, trans Monique Layron, Universicy of Chicago Press, Chicago.

McInerney, Jay, 1986, Bright Lights, Big City. Fontana, London.

- 1987, Ransom, Fontana, London.

—, 1989. Story of My Life, Penguin, London.

- 1992, Brightness Falls, Bloomsbury, London.

Mauss, Marcel, 1993, A Category of the Human Mind: the Notion of Person; the Notion of Self, trans WD Halls, in The Category of the Person, Carrithers et al, eds, Cambridge UP, Cambridge.

Mellencamp, Patricia, 1993-94, 'Haunted History: Tracey Moffatt and Julie Dash', Discourse, 16, 2, 127-63. 
Michaels, Eric, 1987a, 'Review of Fred Myers, Piniupl Cullure, Pintupi Self, Canberra Antbropology, 10, 1, 44-62.

- 1987b, 'The Last of the Nomads, the Last of the Erhnographies or 'All Anthropologists Are Liars': A Review of Fred Myers, Pintupt Country, Pintupl Self, Mankind, 17, 1, 3446.

-, 1994, Bad Aboriginal Art: Tradition, Media, and Tecbnological Horizons, University of Minnesota Press, Minneapolis.

Miller, Daniel, 1987, Matertal Culture and Mass Consumption, Basil Blackwell, Oxford.

Miller, JDB, 1967, The Nature of Politics, Penguin, Harmondsworth.

- 1981. The World of States: Connected Essays, Croom Helm, London.

Miller, Toby, 1994, 'When Australia Became Modem', Continuum, 8, 2, 206.14.

Mosca, Gaetano, 1939, The Ruling Class, trans Hannah D Kahn, rev \& ed Arthur Livingston, McGraw-Hill, New York.

Muecke, Stephen, 1992, Textual Spaces: Aboriginality and Cultural Studies. University of New South Wales Press, Sydney.

Myers, Fred R, 1987, 'Representing Whom? Privilege, Position, and Posturing', Canberra Anibropology, 10, 1, 62-73.

- 1991, Pintupi Couniry, Pintupi Self: Sentiment, Place, and Polltics Among Western Desen Aborigines, University of California Press, Berkeley.

—. 1994, 'Culture-Making: Perforning Aboriginality at the Asia Society Gallery', American Etbnologist, 21, 4, 679-99.

Needham, Rodney, 1970, 'Introduction', in Primitive Classification, Durkheim \& Mauss, Cohen \& West, London.
Newcomb, Horace, ed, 1994a, Television: The Crifical View, 5th ed, Oxford UP, New York.

O'Regan, Tom, 1993, Australian Television Culture, Allen \& Unwin, Sydney.

Parsons, Talcont. 1966, Societies: Evolutionary and Comparative Perspectives, PrenticeHall, Englewood Cliffs.

Rudcliffe-Brown, AR, 1976, Structure and Funcion in Primilive Soctety: Essays and Addresses, Rourledge \& Kegan Paul, London.

Stration, Jon, 1989. 'A Question of Origins', Arena, 89, 133-51.

Tomlinson, John, 1991, Cultural Imperialism: A Crifical Introduction, Pinler Publishers, London.

Turner, Bryan, 1986, Cllizenship and Capilalism: The Debate Over Reformism. Allen \& Unwin, London.

Tumer, Graeme, ed, 1993, Nation, Cullure, Text: Australian Cultural and Media Studies, Routledge, London.

Tumer, Neil, 1990, 'Pitchat and Beyond', Anlink, 10, 1-2, 43-45.

Tyler, William, 1994, 'Crosslines: Aboriginality, Postmodernity and the Austrolian State', Humanity and Society, 18, 1, 4-21.

Weiner, Annette B, 1992, Inalienable Passessions: The Paradax of Keeping-WbileGiving, University of California Press, Berkeley.

Toby Miller is an Assistant Profossor of Cinema Studies at New York University. His publications include The Well-Tempered Self: Citizenship, Culture, and the Postmodern Subject (The John Hopkins UP, 1993) and (with Siwarn Cunningham) Concempomry Austalian Television (UNSW Press, 1994). 